\title{
Do SHRM Body of Competency and Knowledge behavioral competencies be beneficial for Hotel HR Managers? The Case of Cairo Five-Star Hotels \\ Nabeel Badran ${ }^{1,2 *} \quad$ Magdy Maayouf $^{2}$ \\ ${ }^{1}$ College of Business, Jeddah University, KSA \\ ${ }^{2}$ Faculty of Tourism and Hotels, Fayoum University.
}

\begin{abstract}
The Society of Human Resources Management (SHRM) Body of Competency and Knowledge is the basis for the SHRM credentials. The SHRM dictates the behavioral competencies and HR knowledge needed for effective job performance of managers. The current study tries to investigate the importance of the factors dictated by the model of competency (2017 edition) from the viewpoint of HR hotel managers working in five-star hotel chains in Cairo. The study uses a questionnaire design consisting of $33 \mathrm{HR}$ manager. It investigates individual factors that potentially explain the new "competency model" that itemizes what a new HR manager really needs within the context of hotel sector. The study reveals significant benefits of behavioral competencies dictated by the SHRM model 2017 edition. A multiplicity of factors explains the role of these competencies in advancement. The findings indicate that HR managers advancement and success is explained by the model set of factors. The study findings suggest vital practical implications for the development of these competencies within the performance appraisal of HR managers.
\end{abstract}

Keywords: HR Development, SHRM, Hotel Industry, HR Managers, HR Competencies.

\section{Introduction}

Vathanophas \& Thai-ngam (2007) stated that Human assets are one of the most important resources available to any organization and employee competence and commitment largely determine the objectives that an organization can set for itself and to its success in achieving them. Horwitz \& jain (2008) added that "changing patterns of employment are having a dramatic impact on HR policies within organizations." Increasing globalization and fierce competition have their greatest impact on business environment, process, and practices of human resources.

Piwowar-Sulej (2020) added that in the modern world, continuous organizational changes are becoming the norm. They consist of the reorganization of processes, the optimization of the size of an organization, decentralization, and the blurring of organizational boundaries.

The Society of Human Resource Management (SHRM) has a new "competency model" called the SHRM Body of Competency and Knowledge that itemizes what competencies a HR Manager will need. The SHRM established eight behavioral competencies within three categories: Leadership competencies (Leadership \& Navigation, Ethical Practice), Interpersonal competencies (Relationship Management, Communication, Global \& Cultural Effectiveness), and Business competencies (Business Acumen, Consultation, Critical Evaluation) (SHRM BOcK, 2017).

A competency is "a group of highly interrelated knowledge, skills, abilities and other characteristics (KSAOs) that give rise to the behaviors needed to perform a given job effectively" (Carbery et al., 2003). In essence, Vathanophas \& Thai-ngam (2007) argued that competencies are the certain characteristics or abilities (motives, traits, self-concepts, skills and knowledge) of an individual that enable them to perform appropriate specific actions. When the responsibilities

*Corresponding Author, Nabeel Badran, Jeddah Universitym, nbadran@uj.edu.sa 
of the job to produce the desired results require the demonstration of specific actions, an individual draws from inner resources for the capability to respond.

Maaleki (2018) defined the competency as "the set of demonstrable characteristics and skills that enable, and improve the efficiency or performance of a job. These diverse competencies are vital for HR managers. If we spotlight for example on "Critical Evaluation competency" which dictates a group of KSAOs that comprise knowledge of research design, critical thinking skills and deductive reasoning abilities, we will observe its effect when it gives power to HR professionals to support the HR function of their companies (Kim et al. 2020; McGill, 2013).

\section{Description of SHRM model}

Garavan et al., (2006) emphasized that careers are evolving over time and are influenced by characteristics of the individual as well as by organizational factors. These organizations are increasingly under high pressure to attain and retain managerial talents.

According to Hansen (2002) business leaders see new roles and responsibilities emerging for human resource managers Most important, human resource managers must play a more central role by understanding the business direction of their companies, including what products and services it produces, who are its typical customers, and how it is positioned competitively in the market place. Moreover, they must help bring about this transformation by adding significant value to the business through facilitating change with the help of well-planned strategies and processes.

A set of competencies that collectively defines the requirements for effective performance in a specific job, profession or organization may be called a competency model. Competencies include technical competency, behavioral ones. Technical ones reflect the knowledge related to a given profession that is vital for a professional in that career to perform a particular job (ESPERA, 2019; Mustaffa Kamal et al. 2012). The HR Expertise competency in the SHRM Competency Model illustrates the technical knowledge related to the HR field such as these related to talent management, recruiting, or compensation and benefits (www.SHRM.com, 2020).

Ransom \& Yassine (2019) contended that, not only are these competency models important tools to help practitioners improve their knowledge and skills, but also linking them - and the benchmarks they set - to national initiatives can also be beneficial.

In addition, behavioral competencies dictate the KSAOs that enable the application of technical knowledge to job-related behaviors. Gruden \& Stare (2018) emphasized five behavioral competencies (teamwork, leadership, communication, solving of conflicts, and crisis management), giving the sense that professional circles are becoming ever more aware of the importance of behavioral competencies for project performance. These competencies are more general in their nature than technical ones of HR Expertise. For instance, the communication competency enables the executive to communicate across a range of several media (e.g., e-mail and oral presentations) and connected to a diversity of audiences as well (e.g., internal and external partners).

Kim et al. (2020) emphasized that technical competencies are connected to knowledge which HR managers apply to their jobs, and behavioral ones describe how they apply this knowledge. If the HR professionals well capture the two competencies, they will get high profession success. This means that success emerges not only from what HR manger really know (knowledge competencies) but also what he/she do (behavioral competencies). 


\section{Leadership and Navigation}

The knowledge, abilities, skills, and other characteristics (KSAOs) are vital to navigate the company and achieve HR goals, to provide a compelling vision and mission for HR that coincide with the strategic plan of the organization and culture, to lead and achieve organizational renewal and transformation, (Kakabadse, 2007) to lead the implementation and execution of HR initiatives, and to enhance the role of HR as a vital key business strategic partner. Apart from enhancing the status of the HR department, past research also suggests that the competency level of HR managers has a major influence on the level of integration between HR management and strategy (Khatri, 2009; Sheard, 2007).

Moore et al. (2020) stated that HR managers are positioned to play a strategic role in companywide integration. They play a highly significant role in managing and integrating post-merger processes. The HR function is signaled as central to the success of any HR initiative. A major issue in some organization's failures might be caused where there is poorly defined intent and there is too little involvement of the HR function and organizational employees.

\section{Ethical Practice}

Ethical practice refers to the course of conduct which includes the characteristics needed to achieve high levels of personal and professional integrity which is widely regarded as a key virtue for professionals (Eriksen, 2015), and to act as an ethical agent who support the organization core values, integrity and accountability (Woods \& Kakabadse, 2007).

\section{Relationship Management}

Relationship management refers to the knowledge, abilities, skills, and other characteristics vital to create and maintain an effective network of professional contacts within and outside of the organization. These relationships are vital to the organizational success and is considered as a capital which should be developed and maintained. This competency comprises HR manager's skills needed to act as an effective member of a team, and to effectively manage workplace conflicts and positive negotiations while supporting the organization activities (Sheard and Kakabadse, 2006).

Brahim \&Raboudi (2020) emphasized that CRM is highly being used in the hotel industry since the domain implicates to have a direct relationship with clients and hotel industry leaders have though a lot about the role of technology to effectively build CRM. If hospitality organizations want to compete successfully, they must do so by using technology to drive value to both the customer and to the firm".

\section{Communication}

Communication competence involves knowledge, abilities and skills needed to effectively make and well deliver concise and informative communications. The competency also includes how to listen to and address the concerns of entitled persons and how to transfer and interpret information from specific level or unit of the organization to another one (Khatri, 2009). In essence, Kohont \& Brewster (2014) argued that Both CEOs and expatriates emphasized the communication competency within HR vital managerial competencies.

\section{Global \& Cultural Effectiveness}

The competency here includes the KSAOs vital to consider and value the expected and backgrounds of all entitled parties, and to fully interact with others in a global level, and to well promote a diversity and inclusiveness of surrounded workplace. To shed light on how CEOs and managers contribute to workplace diversity management, $\mathrm{Ng} \&$ Sears (2020) emphasized the process through which CEO commitment to diversity translates into the implementation of diversity management practices. 


\section{Business Acumen}

The competency here refers to the KSAOs important to fully understand the organization's processes, functions and external environment, and to introduce business tools and analyses that inform HR initiatives and operations that agree with the overall strategic direction of the organization. Sandstrom \& Reynolds (2020) stated that The HR manager's role demands sophisticated talent, with global acumen, multi-cultural perspective, people-handling skills, technological proficiency, strategic and entrepreneurial skills and the ability to manage an increasingly delayered organization.

\section{Consultation}

Consultation competency comprises skills related to work with stakeholders in assessing business challenges and opportunities for the design, implementation and assessing of organizational development initiatives, and to build continuous support for HR solutions that meet the rapid changing needs of both customers and the business (www.SHRM.com, 2020)

\section{Critical Evaluation}

The critical evaluation includes skills which are critical to collect and analyze both qualitative and quantitative data, and to interpret and related findings that assess HR initiatives and inform business decisions and recommendations to specific partners(www.SHRM.com, 2020).

\section{Research design and methodology}

For this study, the researcher utilized a quantitative methodology using questionnaire approach. The study uses the descriptive strategy to research the current situation and the objectives of the study. The principal aim of the study was to spotlight on an inter-organizational behavioral and knowledge competencies of HR executives in the light of SHRM body of competency and knowledge to depict the importance of the model within HR operations in Five-star hotels in Cairo. The study accredited the model of 2017 issued by SHRM and adopted the elements of each competency in 2017 edition in the study survey questions.

\section{Data collection}

Secondary research focused on a comprehensive literature review with data sourced from social science journal publications, electronic books as well as the Internet, which considered to be valuable secondary resources for statistical data. Primary research consisted of data collected via quantitative methods using electronic survey provided to executives of HR.

33 HR executives in five-star hotels in Cairo are positively shared the study. HR executives were selected purposively for the purposes of this study. A questionnaire is considered to be the most appropriate tool to reach the purposive population sample (33) across five-star hotels. Depending on the model adopted by SHRM in 2017 edition, the study adopted a closed structured questionnaire to investigate the viewpoint of HR executives in the Egyptian Hotel industry context.

The questionnaires distributed to HR executives via e-mail. The survey included HR managers of hotels of 33 respondents. The study was employed to assess the management challenges and as well as to gain an insight into HR executives' perceptions on the competencies tabulated within SHRM body of competency. A total of 33 questionnaires were positively obtained.

Result descriptives, simple correlations, and coefficient alpha reliability estimates are presented for all variables of the study. Reliabilities for all scales are well above the generally accepted level of 0.70 . the study uses 5 Likert scale of degree of importance (strongly important, important, neutral, not important, not important at all). 


\section{Hypothesis}

H1. There is no significant difference among opinions of managers that the eight SHRM competencies are important.

H2. There is a positive correlation between the eight SHRM competencies and career advancement.

\section{Results and discussions}

Variable 1. Leadership \&Navigation Competencies.

Table 1. leadership assessment items

\begin{tabular}{|c|c|c|c|}
\hline Items & Mean & SD & Order \\
\hline $\begin{array}{l}\text { Demonstrates an understanding of formal and informal work roles, } \\
\text { leader goals and interests, and relationships among employees. }\end{array}$ & 4.02 & 1.01 & 3 \\
\hline $\begin{array}{l}\text { Facilitates communication and decision-making necessary to implement } \\
\text { initiatives. }\end{array}$ & 3.78 & 0.008 & 6 \\
\hline $\begin{array}{l}\text { Uses an understanding of the organization's processes, systems and } \\
\text { policies to facilitate the successful implementation of HR initiatives. }\end{array}$ & 4.00 & 0.007 & 4 \\
\hline $\begin{array}{l}\text { Uses awareness and understanding of the organization's political } \\
\text { environment and culture to implement HR initiatives. }\end{array}$ & 3.02 & 0.03 & 7 \\
\hline $\begin{array}{l}\text { Embraces and supports the business unit's and/or organization's culture, } \\
\text { values, mission and goals. }\end{array}$ & 3.84 & 0.005 & 5 \\
\hline $\begin{array}{l}\text { Identifies opportunities to improve HR operations that better align with } \\
\text { and support the strategic vision of HR and the organization. }\end{array}$ & 4.09 & 0.098 & 2 \\
\hline Builds credibility as an HR expert within and outside of the organization. & 4.60 & 1.10 & 1 \\
\hline $\begin{array}{l}\text { Motivates HR staff and other stakeholders to support HR's vision and } \\
\text { goals. }\end{array}$ & 2.90 & 0.92 & 8 \\
\hline Total mean & 3.87 & 0.44 & \\
\hline
\end{tabular}

Table (1) indicates that the most important competency within the cluster of leadership was building credibility. Credibility is vital for business leader as it provide psychological support to employees and enhance the internal and external trust and enable the manager to be a good example to others. This competency was very important for HR managers as indicated in the above table, mean (4.6). Credibility outside the organization with other stakeholders is critical as well.

Within the results, HR executives must build healthy relationships with all stakeholders for the benefits of hotel business as this is the stem of service industry. HR executives should have strategic motives and always support the overall business strategy. The leader should be creative and should has long strategic sense outside his closed department.

The main role of leaders is to demonstrate roles and lead work environment. Maintaining healthy relationship is an important role of the leader. Respondents give an important rate to that issue, mean (4.02). The executive is the responsible of interpreting policies of the organization into activities and he must implement the department-initiated programs according to the organization ones. This is coinciding with Sawyer (2019) who indicated that the Executive should link the initiatives of his processes with company's goals, through a thorough understanding of department aims, objectives, and mission. He 'll need to be able to articulate both short-term and long-term plans for growth to the relevant HR personnel.

Items formed this competency, like using awareness and understanding of the organization's political environment and culture to implement HR initiatives, scored the lowest importance from the viewpoint of the respondents. In strategic corporate performance, these items are so important 
especially in the era of uncertainty which made the organization in simultaneous need to capture and use the external environment indicators as leading clues in the future initiatives.

\section{Variable 2. Ethical Practice Competencies}

Table 2. Ethical assessment items

\begin{tabular}{l|l|l|c}
\hline Items & Mean & SD & Order \\
\hline Serves as a role model of personal integrity and high ethical standards. & 3.66 & 0.006 & 7 \\
\hline $\begin{array}{l}\text { Maintains privacy, in compliance with laws and regulations mandating a } \\
\text { duty to report unethical behavior. }\end{array}$ & 3.88 & 0.21 & 6 \\
\hline $\begin{array}{l}\text { Maintains current knowledge of ethics laws, standards, legislation and } \\
\text { emerging trends that may affect organizational HR practice. }\end{array}$ & 4.00 & 0.01 & 4.5 \\
\hline $\begin{array}{l}\text { Leads HR investigations of employees in a thorough, timely and impartial } \\
\text { manner. }\end{array}$ & 4.00 & 0.008 & 4.5 \\
\hline $\begin{array}{l}\text { Provides open, honest and constructive feedback to colleagues when } \\
\text { situations involving questions of ethics arise. }\end{array}$ & 4.22 & 0.003 & 1 \\
\hline $\begin{array}{l}\text { Empowers all employees to report unethical behaviors and conflicts of } \\
\text { interest without fear of reprisal. }\end{array}$ & 4.06 & 0.023 & 2 \\
\hline $\begin{array}{l}\text { Maintains appropriate levels of transparency for HR programs, practices and } \\
\text { policies. }\end{array}$ & 3.33 & 0.009 & 8 \\
\hline $\begin{array}{l}\text { Ensures that staff members have access to and understand the organization's } \\
\text { ethical standards and policies. }\end{array}$ & 4.04 & 0.023 & 3 \\
\hline Total mean & 3.9 & 0.2 & \\
\hline
\end{tabular}

Ethics is one of the important components that enable the organization to protect its values and culture. Ethical practices are vital to the success of any manager. SHRM body of competency and knowledge listed ethical practices of HR manager as a main indicator and competency of going through the future. Respondents here emphasized that this competency is important within the hotel industry (3.9). According to the model, HR executive should serve as a role model of personal integrity and high ethical standards.

In spite, respondents score here is (3.66). The main item of competency which have direct impact realized by any leader is to be a good example for his employees especially in the service industry. The manager provides role of model in all ethical practices for his collogues that emphasizes ethical adoption of the culture and strategy of the whole organization. Paine (2015) argued that executives must acknowledge the role in conforming organizational ethics and seize this chance to create an overall climate that can strengthen the relationships and reputations on which their organizations' success depends. Executives who ignore ethics run the risk of personal and corporate liability in today's increasingly tough legal environment.

Compliance with laws and regulations is a cornerstone in the reputation of service industries. This mandates the executives a duty to report unethical behavior. This issue forms the extent to which the manager to be integrated with ethics and policies of the organization he was appointed for. Ignoring such laws may be costly for the organization and the employees. Service industry depends mainly on the skills and characteristics of the HR personnel, so these competencies are really important. Also, the product of the hotel industry is mainly impacted by the ethics of people as it is difficult to be standardized.

Ethics are being formulated by the strategy of the organization. Davis \&Carnovali (2019) pointed out that the human resources (HR) function is at the center of most employers' efforts to identify, hire and retain the employees the organization wants to execute its strategy and achieve its strategic goals. This HR function is a vital player within the organization's compliance structure as well. There are numerous laws and regulations governing the employment relationship that 
HR professionals must understand and emphasize to help ensuring their organizations avoid costly fines and other penalties, including the potential harm to the organization's reputation.

Variable 3. Relationship Management Competencies.

Table 3. relationship management assessment items

\begin{tabular}{l|l|l|l}
\hline Items & Mean & SD & Order \\
\hline $\begin{array}{l}\text { Develops and maintains a network of professional contacts within the } \\
\text { organization, including peers in both HR and non-HR roles, HR customers and } \\
\text { stakeholders }\end{array}$ & 3.01 & 0.004 & 6 \\
\hline Develops and maintains a network of external partners (e.g., vendors). & 3.33 & 0.004 & 4 \\
\hline Develops and maintains mutual trust and respect with colleagues. & 3.44 & 1.1 & 2.5 \\
\hline $\begin{array}{l}\text { Develops and maintains a pattern of reciprocal exchanges of support, } \\
\text { information and other valued resources with colleagues. }\end{array}$ & 4.01 & 1.02 & 1 \\
\hline $\begin{array}{l}\text { Establishes a strong and positive reputation, within and outside the organization, } \\
\text { as an open and approachable HR professional. }\end{array}$ & 3.00 & 1.04 & 7 \\
\hline $\begin{array}{l}\text { Ensures that all stakeholder voices are heard and acknowledged. } \\
\text { Fosters collaboration and open communication among stakeholders and team } \\
\text { members. }\end{array}$ & 2.60 & 0.003 & 9 \\
\hline $\begin{array}{l}\text { Resolves and/or mediates conflicts in a respectful, appropriate and impartial } \\
\text { manner, and refers them to a higher level when warranted. }\end{array}$ & 3.44 & 0.003 & 8 \\
\hline $\begin{array}{l}\text { Applies an understanding of the needs, interests, issues and bargaining position } \\
\text { of all parties to negotiation discussions. }\end{array}$ & 3.02 & 0.021 & 2.5 \\
\hline \begin{tabular}{l} 
Total Mean \\
\hline
\end{tabular} & 3.1 & 0.60 & 5 \\
\hline
\end{tabular}

Managers especially the executive ones have four main relationships within their profession within any organization. These four levels of relationship include vertical, horizontal, downward and outside the organization relationship. These four-level relationships need to be managed effectively for the success of the whole system.

SHRM model emphasized a cluster of relationship management. HR executive should develop and maintains a pattern of reciprocal exchanges of support, information and other valued resources with colleagues (4.01). That item of the competency was viewed as important according to the viewpoint of HR executives. This might be due to the relation between the item and the real profession of managers. Goals might be attained if they ignore maintaining support and information, so this competency item was important as well.

While other items of the competency like keeping professional contacts with different peers, HR customers and stakeholders were less important according to respondents' viewpoint. Healthy relationship management is so vital to all executives and is considered one of the most important elements of total capital of the organization in the marketplace. Accordingly, open communication among stakeholders and team members was also unimportant from the same viewpoint. The total mean was accordingly law (3.1).

To effectively manage workplace conflicts, you must be a competent communicator. This includes creating an open communication channels in your department by encouraging people to talk about work issues. Listening to employee problems and dilemmas will foster an open environment. Make a fully understand of what employees are saying by asking questions and focusing on their perception of the problem to give overall feedback. Executive should take care that the immediate response to conflict situations is essential. 


\section{Variable 4. Communication Competencies}

Table 4. communication assessment items

\begin{tabular}{l|l|l|l}
\hline Items & Mean & SD & Order \\
\hline $\begin{array}{l}\text { Effectively communicates HR programs, practices and policies to both HR and } \\
\text { non-HR employees. }\end{array}$ & 3.45 & 0.011 & 8 \\
\hline $\begin{array}{l}\text { Voices support for HR and organizational initiatives in communications with } \\
\text { stekeholders. }\end{array}$ & 4.12 & 0.002 & 2 \\
\hline Effectively communicates with senior HR leaders & 3.87 & 0.033 & 5 \\
\hline Seeks further information to clarify ambiguity. & 3.56 & 0.023 & 7 \\
\hline Promptly responds to and addresses stakeholder communications. & 4.08 & 0.003 & 3 \\
\hline $\begin{array}{l}\text { Interprets and understands the context of motives for and reasoning in received } \\
\text { communications. }\end{array}$ & 4.60 & 0.0231 & 1 \\
\hline Ensures that the delivered message is clear and understood by the listener. & 3.75 & 0.011 & 6 \\
\hline Uses appropriate business terms and vocabulary. & 4.00 & 0.003 & 4 \\
\hline $\begin{array}{l}\text { Uses an understanding of the audience to craft the content of communications } \\
\text { (e.g., translates technical jargon), and chooses the best medium for } \\
\text { communication. }\end{array}$ & 3.02 & 0.01 & 9 \\
\hline Grand Total & & & \\
\hline
\end{tabular}

Communication skills are the most important competencies of all hotel and service staff as they depend mainly on their communication to offer the service to guests and clients. HR executive needs communication as much as experience. The SHRM competency model declares that HR manager should effectively communicate HR programs, support for HR and organizational initiatives in communications with stakeholders, communicate with senior HR leaders. These technical elements of the competency were viewed as important as shown in table (4).

If a wide gap exists between HR strategy and what exactly needed by the corporate strategy, the problem here is a communication one. Employees in the service industry should reflect all elements to help realize the strategy and should be committed to make effective communication as vital priority. Simultaneous and effective two-way communication with the staff should be one of the manger prominent values. It is a great error to think that strong communication comes set aside during peak seasons when it should be as a great priority.

Competent communication allows employees in the business to be good performers who work with each other in a healthier way, are to be happier and work safer. Simply, the action of no communication or feedback can harm the entire HR business. No matter what the size of the corporate is, you need to well make your subordinates know about what's happening in the whole operation. Feedback also important and must be built into the whole process. Whether you coincide with the feedback or disagree, it will provide you with insight into how your employees is feeling and make them know your care that you will listen to their voice. Communication within service industry will allow the manager and his staff to be on the same page.

Variable 5. Global \& Cultural Effectiveness Competencies

Table 5. cultural assessment items

\begin{tabular}{llll}
\hline Items & Mean & SD & Order \\
\hline $\begin{array}{l}\text { Demonstrates a general awareness and understanding of and respect for } \\
\text { cultural differences and issues. }\end{array}$ & 4.19 & 0.004 & 1 \\
\hline $\begin{array}{l}\text { Adapts behavior to navigate different cultural conditions, situations and } \\
\text { people. }\end{array}$ & 3.44 & 1.1 & 2 \\
\hline $\begin{array}{l}\text { Demonstrates acceptance of colleagues from different cultures. } \\
\text { Promotes the benefits of a diverse and inclusive workforce. }\end{array}$ & 2.80 & 1.02 & 4.5 \\
\hline Promotes inclusion in daily interactions with others. & 2.33 & 1.04 & 8 \\
\hline
\end{tabular}




\begin{tabular}{llll} 
Items & Mean & SD & Order \\
\hline $\begin{array}{l}\text { Conducts business with an understanding of and respect for cross-cultural } \\
\text { differences in customs and acceptable behaviors. }\end{array}$ & 2.04 & 0.003 & 10 \\
\hline $\begin{array}{l}\text { Supports an organizational culture that values diversity and promotes } \\
\text { inclusion. }\end{array}$ & 2.80 & 0.01 & 4.5 \\
$\begin{array}{l}\text { Uses the organization's policies and philosophy toward diversity and } \\
\text { inclusion to inform business decisions and implementation of HR programs, } \\
\text { practices and policies. }\end{array}$ & 2.09 & 0.021 & 9 \\
\hline $\begin{array}{l}\text { Designs, recommends, implements, and/or audits HR programs, practices } \\
\text { and policies intended to ensure diversity and inclusion. }\end{array}$ & 2.54 & 0.03 & 7 \\
\hline $\begin{array}{l}\text { Ensures that HR programs, practices and policies are applied consistently } \\
\text { and respectfully to all staff. }\end{array}$ & 3.20 & 0.34 & 3 \\
\hline Grand Total & 2.8 & 0.80 \\
\hline
\end{tabular}

Cultural differences and diversity issues are important factors affect any business today. The world has become more diverse and more dynamic as well. Globalization affects business around the world and the firm that can make best use of diversity of its staff, will become more competitive. Hotel industry is a labor-intensive sector.

In middle east region, diversity is eventually low issue as the pool of staff is almost similar. The respondents her put a low importance (2.8) to that issue of competency cluster. HR executive should demonstrate a general awareness and understanding of and respect for cultural differences and issues. The advantages of diversity are really important to the organization and the people entitled. In the fierce international competition, Hotels should capitalize in the diversity context of its staff for the sake of the entire company.

\section{Variable 6. Business Acumen Competencies}

Table 6. business acumen assessment items

\begin{tabular}{llll}
\hline Items & Mean & SD & Order \\
\hline $\begin{array}{l}\text { Uses organizational and external resources to learn about the organization's } \\
\text { business operations, functions, products and services. }\end{array}$ & 3.88 & 0.0323 & 5 \\
\hline $\begin{array}{l}\text { Applies knowledge of the organization's business operations, functions, } \\
\text { products and services, in order to implement HR solutions and inform } \\
\text { business decisions. }\end{array}$ & 3.47 & 0.21 & 7 \\
\hline $\begin{array}{l}\text { Uses cost-benefit analysis, organizational metrics and key performance } \\
\text { indicators to inform business decisions. }\end{array}$ & 3.75 & 0.22 & 6 \\
\hline $\begin{array}{l}\text { Applies principles of finance, marketing, economics, sales, technology, law } \\
\text { and business systems to internal HR programs, practices and policies. }\end{array}$ & 4.20 & 0.004 & 2 \\
\hline $\begin{array}{l}\text { Uses HR information systems (HRIS) and business technology to solve } \\
\text { problems and address needs. }\end{array}$ & 4.02 & 0.01 & \multirow{2}{*}{4} \\
\hline $\begin{array}{l}\text { Demonstrates an understanding of the relationship between effective HR } \\
\text { and effective core business functions. }\end{array}$ & 4.22 & 0.11 & 1 \\
\hline $\begin{array}{l}\text { Aligns decisions with HR's and the organization's strategic direction and } \\
\text { goals. }\end{array}$ & 4.13 & 0.22 & 3 \\
\hline Grand Total & & & \\
\hline
\end{tabular}

Business acumen is keenness and quickness in understanding and dealing with a "business situation" (risks and opportunities) in a manner that is likely to lead to a good outcome. Additionally, business acumen has emerged as a vehicle for improving financial performance and leadership development. Consequently, several different types of strategies have developed around improving business acumen (Wikipedia, 2020). Business acumen is an important competency cluster emphasized by respondent (3.81). HR executive should support the 
organization's business operations, functions, products and services. This is important for hotel industry where everlasting innovations have no end. HR executive should apply professional knowledge to implement HR solutions and inform business decisions.

The manager will take wrong decisions if data and information were not collected and interpreted effectively. HR executive should use cost-benefit analysis because cost is a vital indicator of good administration. Hotel industry costs are big number so, the executive should carefully analyze costs and beneficiary profit-cost analysis. They should use HR information systems (HRIS) and business technology to solve problems and address needs because technology in service industry and especially in HR processes are important. It is the most factor affect the whole business. It is the chance of executives to best use of technology to best control operations and benefit from promptness of the business.

\section{Variable 7. Consultation Competencies}

Table 7. consultation assessment items

\begin{tabular}{llll}
\hline Items & Mean & SD & Order \\
\hline Identifies current and future HR-related threats and liabilities. & 3.88 & 0.23 & 6 \\
\hline $\begin{array}{l}\text { Identifies existing HR programs, practices and policies that impede or } \\
\text { support business success. }\end{array}$ & 3.45 & 0.011 & 9 \\
\hline $\begin{array}{l}\text { Offers, in partnership with stakeholders, HR solutions for business needs } \\
\text { that are creative, innovative, effective and based on best practices and/or } \\
\text { research. }\end{array}$ & 4.22 & 0.002 & 1 \\
\hline $\begin{array}{l}\text { Provides guidance to non-HR managers regarding HR practices, } \\
\text { compliance, laws, regulations and ethics. }\end{array}$ & 4.20 & 0.09 & 2 \\
\hline $\begin{array}{l}\text { Defines clear goals and outcomes for HR solutions, using them to drive } \\
\text { solution design. }\end{array}$ & 4.00 & 0.002 & 5 \\
\hline $\begin{array}{l}\text { Provides follow-up to and ongoing support for implementation of HR } \\
\text { solutions, to ensure their continued effectiveness. }\end{array}$ & 4.03 & 0.007 & 4 \\
\hline $\begin{array}{l}\text { Identifies, defines and clarifies customer needs and requirements, and } \\
\text { reports on the status of HR services provided and results achieved. }\end{array}$ & 3.76 & 0.04 & 8 \\
\hline $\begin{array}{l}\text { Responds promptly, courteously and openly to customer requests, and takes } \\
\text { ownership of customer needs. }\end{array}$ & 3.80 & 0.02 & 7 \\
\hline $\begin{array}{l}\text { Identifies and resolves risks and early-stage problems in meeting customer } \\
\text { needs. }\end{array}$ & 4.07 & 0.12 & 3 \\
\hline $\begin{array}{l}\text { Total mean } \\
\text { Table (7) }\end{array}$ & 3.83 & 0.1 & \\
\hline
\end{tabular}

Table (7) illustrates the cluster of consultation. Consultation is vital to executives who will take decisions especially strategic ones. HR executives should identify current and future HR-related threats and liabilities so, this is important competence vital for strategy building and reengineering. Here, consultation with other parties and entitled responsible executive is so important for HR managers to select initiatives parallel with the road map of the strategy.

The responsible party of HR is the executives, and they should provide guidance and support for others especially guests and customers as others should provide them with other areas consultation. This is the most important factor concerning and relating the hospitality industry and service industry in all. Guests are the backbone of the whole operation and should be cred and listened carefully. HR executives should respond promptly, courteously, and openly to customer requests, and takes ownership of customer needs and feedback. Such important feedback can result a clear overview or footprint of the HR function in a particular service sector. It can present fresh insights and help the HR profession to emphasize its efforts in areas that add value to the whole business. 


\section{Variable 8. Critical Evaluation Competencies}

Table 8. critical evaluation assessment items

\begin{tabular}{|c|c|c|c|}
\hline Items & Mean & SD & Order \\
\hline Promotes the importance of evidence-based decision-making. & 3.24 & 0.005 & 10 \\
\hline $\begin{array}{l}\text { Uses research findings to evaluate different courses of action and their } \\
\text { impacts on the organization. }\end{array}$ & 3.56 & 0.005 & 8 \\
\hline Reports key findings to senior business and HR leaders. & 4.00 & 0.03 & 6 \\
\hline $\begin{array}{l}\text { Conducts analyses to identify evidence-based best practices, evaluate HR } \\
\text { initiatives and determine critical findings. }\end{array}$ & 4.33 & 0.02 & 1 \\
\hline $\begin{array}{l}\text { Benchmarks HR initiatives and outcomes against the organization's } \\
\text { competition and other relevant comparison groups. }\end{array}$ & 4.01 & 0.03 & 4.5 \\
\hline $\begin{array}{l}\text { Gathers data using appropriate methods (e.g., surveys, focus groups) to } \\
\text { inform and monitor organizational solutions. }\end{array}$ & 3.42 & 0.3 & 9 \\
\hline $\begin{array}{l}\text { Maintains working knowledge of data collection, research methods, } \\
\text { benchmarks and HR metrics. }\end{array}$ & 3.70 & 0.1 & 7 \\
\hline Identifies decision points that can be informed by data and evidence. & 4.01 & 0.023 & 4.5 \\
\hline Maintains objectivity when interpreting data. & 4.10 & 0.053 & 2 \\
\hline $\begin{array}{l}\text { Ensures that HR programs, practices and policies reflect research findings } \\
\text { and best practices. }\end{array}$ & 4.09 & 0.043 & 3 \\
\hline Grand Total & 3.8 & 0.07 & \\
\hline
\end{tabular}

Critical Evaluation Competencies cluster amended by SHRM are critical to hotel industry. The service industry is simultaneously changed so, executives should always think critically to innovate solutions and initiatives. Evidence based management protect decisions of managers. It also supports objectivity to the process. Evidence based management depend mainly on facts and nothing but facts.

HR executives should use research findings to support facts and shall solve problems in the right way. The top management shouldn't rely on findings without clarification of related data for the objectivity of their decisions in the era of globalization and technology. The analysis of data is the vital step which translate it to really useful information.

\section{Variable 9. Career advancement}

Table 9. HR executives career advancement

\begin{tabular}{llll} 
Items & Mean & SD & Order \\
\hline HR executives should have needed knowledge to advance in their careers & 4.24 & 0.025 & 2 \\
\hline Professionals need planning to do to advance their own careers & 4.56 & 0.045 & 1 \\
\hline What HR executives doing today supports their future employability. & 4.20 & 0.032 & 3 \\
\hline Communication skills advances HR executives through their careers & 4.00 & 0.022 & 5 \\
\hline HR executives held their ownership of their own career & 4.11 & $0 . .23$ & 4 \\
\hline HR executives need leadership skills through their career advancement & 3.88 & 0.34 & 6 \\
\hline $\begin{array}{l}\text { HR executives career advancement should be Aligned with key } \\
\text { organizational goals }\end{array}$ & 3.8 & 0.334 & 7 \\
\hline Total mean & 4.14 & 0.0453
\end{tabular}

Respondent assured the importance of factors needed to build career advancement. Career advancement is the responsibility of the executives' skills and they have to be responsible of acquiring the needed skills. It's a manager's job to ensure that his or her competencies are being developed both to perform their current job and, if appropriate, their next role. Both technical and behavioral skills are needed for any advancement as well (Garavan \&O'Hanlon, 2006).

HR managers oversee their departments and are responsible for hiring and firing of employees. They typically consult with other upper-level managers in a company, ensure compliance with 
employment laws, and develop appropriate compensation strategies. Typically, individuals move into these positions with experience and competencies in other human resources positions. However, a master's degree or certification through professional organizations, such as the Society for Human Resources Management, may be helpful in seeking human resources manager positions (www.study.com).

\section{Testing hypotheses}

Table 10. F test

\begin{tabular}{|c|c|c|c|c|c|}
\hline \multicolumn{6}{|c|}{ Independent Samples Test } \\
\hline & & \multicolumn{2}{|c|}{$\begin{array}{l}\text { Levene's Test for } \\
\text { Equality of } \\
\text { Variances }\end{array}$} & \multicolumn{2}{|c|}{$\begin{array}{l}\text { t-test for Equality of } \\
\text { Means }\end{array}$} \\
\hline & & $\mathbf{F}$ & Sig. & $\mathbf{t}$ & Sig. (2-tailed) \\
\hline \multirow{2}{*}{$\begin{array}{l}\text { Leadership \& } \\
\text { Navigation }\end{array}$} & Equal variances assumed & .028 & .883 & -.259 & .796 \\
\hline & Equal variances not assumed & & & $-.260-$ & .795 \\
\hline \multirow[t]{2}{*}{ Ethical Practice } & Equal variances assumed & .029 & .924 & $-.307-$ & .759 \\
\hline & Equal variances not assumed & & & $-.306-$ & .760 \\
\hline \multirow{2}{*}{$\begin{array}{l}\text { Relationship } \\
\text { Management }\end{array}$} & Equal variances assumed & .039 & .861 & $-.078-$ & .938 \\
\hline & Equal variances not assumed & & & $-.078-$ & .938 \\
\hline \multirow[t]{2}{*}{ Communication } & Equal variances assumed & .075 & .966 & $-.233-$ & $.7 \cdot 6$ \\
\hline & Equal variances not assumed & & & $-.254-$ & .745 \\
\hline \multirow{2}{*}{$\begin{array}{l}\text { Global \& Cultural } \\
\text { Effectiveness }\end{array}$} & Equal variances assumed & .382 & .0421 & $-.0302-$ & .0122 \\
\hline & Equal variances not assumed & & & $-.0304-$ & .0360 \\
\hline \multirow[t]{2}{*}{ Business Acumen } & Equal variances assumed & .0234 & .099 & $-.078-$ & .938 \\
\hline & Equal variances not assumed & & & $-.078-$ & .938 \\
\hline \multirow[t]{2}{*}{ Consultation } & Equal variances assumed & .024 & .983 & $-.664-$ & .714 \\
\hline & Equal variances not assumed & & & $-.660-$ & .734 \\
\hline \multirow[t]{2}{*}{ Critical Evaluation } & Equal variances assumed & .034 & .323 & $-.432-$ & .888 \\
\hline & Equal variances not assumed & & & $-.543-$ & .884 \\
\hline
\end{tabular}

Table (10) results indicate that there is no significant difference between means except the fifth competency. This means that the viewpoint of respondents towards the competencies was that they are important to HR executive. They think it is not important to have the competency of global and cultural effectiveness. The first hypothesis is invalid.

Table 11. Correlation analysis

\begin{tabular}{|c|c|c|c|c|c|c|}
\hline \multirow{2}{*}{\multicolumn{2}{|c|}{ Model }} & \multicolumn{2}{|c|}{$\begin{array}{l}\text { Unstandardized } \\
\text { Coefficients }\end{array}$} & \multirow{2}{*}{$\begin{array}{l}\text { Standardized } \\
\text { Coefficients } \\
\text { Beta } \\
\end{array}$} & \multirow[t]{2}{*}{$\mathbf{t}$} & \multirow[t]{2}{*}{ Sig. } \\
\hline & & B & Std. Error & & & \\
\hline \multirow[t]{9}{*}{1} & (Constant) & 6.400 & .383 & & 16.705 & .000 \\
\hline & Leadership \& Navigation & $-.119-$ & .027 & .314 & $-4.321-$ & .000 \\
\hline & Ethical Practice & $-.102-$ & .031 & .217 & $-3.882-$ & .000 \\
\hline & Relationship Management & .067 & .024 & .164 & 2.553 & .011 \\
\hline & Communication & $-.172-$ & .040 & .321 & $-4.305-$ & .000 \\
\hline & Global \& Cultural Effectiveness & $-.164-$ & .023 & .416 & $-7.274-$ & .040 \\
\hline & Business Acumen & $-.092-$ & .035 & .200 & $-2.677-$ & .008 \\
\hline & Consultation & $-.079-$ & .034 & .140 & $-2.347-$ & .020 \\
\hline & Critical Evaluation & $-.085-$ & .022 & .203 & $-3.804-$ & .000 \\
\hline
\end{tabular}


Table (11) indicates a positive correlation between seven competencies and career advancement. There is a relation between all factors of the competencies and career advancement except the fifth competency (global \& cultural effectiveness. According to these correlations, the second hypothesis is invalid.

\section{Summary and implications}

The main challenge for HR managers in their current situation was identified as dealing with human resource management diversity. The SHRM competency model is important in the viewpoint of hotel HR executives at present. HR executives emphasized the importance of seven competences which are as commonplace in the hospitality industry. It is critical for hotels to invest in new skills through clusters emphasized within the SHRM competency model. This also gives them the opportunity to exploit the new competency model according to the actual and modern practices and processes in the field worldwide and to enhance their hotels' competitive advantage. It is important for them to realize that by acquiring these competencies and skills, they will not only increase their knowledge, but their core competencies and staff competencies as well.

This can help them to face their management challenges and issues. It was therefore proposed that the competency modules incorporated the necessary skills within the era of fierce competition. Hotels should facilitate their transition towards competencies required. The aim is to raise awareness on the necessity of how they can play a fundamental role in improving the day-to-day operation of HR in the long term. Hotel management should provide a better understanding of what they need to achieve to improve their competitive advantage according to the model recommendation and manual.

Another important priority of the competency model of SHRM is to assess the future quality of future managers' needs. The provision of consistent and accurate skills at the right time can support effective training and help managers and employees to acquire the appropriate knowledge and skills. They can then apply this knowledge to improve individual and organizational strategic performance that may be linked to a reduction in higher employee turnover and overall performance as well. Therefore, the model could be accredited by entitled authorities, professionals, universities and the private sector to grant official recognition and reward for training-based initiatives. This may then enable employees to gradually develop their competency portfolio to achieve university degrees or professional qualifications and may provide more of an incentive to participate in training programs.

\section{Recommendations}

It is important to create conditions that are in favor of competency acquiring and to eliminate barriers that prevent people from participating in development and training environment. Enabling staff as a prior step to participate in training on the SHRM model of competency is vital. Otherwise the immediate application of the competency model items can be a less satisfying experience and discourage employees from engaging in it before the infrastructure needed be placed. Training on the competencies needed is also only possible when the appropriate infrastructure and technology is in place.

The provision of incentives and funding by government to HR executives that invest in developing their competencies within their organizations may help to promote broader access to future managers who equipped with skills needed for that future with continuous changing conditions.

With these leading competencies, the government, universities and the private sector should invest in research and development aimed at furthering the understanding of best practices in 
future competencies along with its delivery and service. Technology can be introduced to simplify the competency items, facilitate the adoption needed and capture the culture need to be assessed for all associated parties.

The career advancement of hotel managers should be linked to such competency model to be a basic part within the appraisal of managers of HR. Commitment to development and career are important. Career commitment appeared to be particularly important. In order to create this culture, hotels need to formulate clear policies and encourage initiatives that emphasize the importance of continuous learning and development for managerial effectiveness and provide rewards-based advancement to those who utilize their skills and competencies.

\section{References}

Brahim, A. B. \& Raboudi, W., (2020), Improving Customer Relationship Management using Machine Learning techniques: A Tunisian Case Study, 2020 International Multi-Conference on: "Organization of Knowledge and Advanced Technologies" (OCTA), Tunis, Tunisia. 116 ,

Carbery, R., Garavan, T.N., O’Brien, F. and McDonnell, J. (2003), Predicting hotel managers' turnover cognitions, Journal of Managerial Psychology, vol. 18(7), 649-79.

Davis, R. \& Carnovali, M., (2019), The HR Function's Compliance Role, in Featured, HR Compliance, https://hbr.org.

Eriksen, A. (2015), What is professional integrity? Nordic Journal of Applied Ethics, 9 (2), 3-17.

ESPERA, A. H. (2019), Exploring Challenges in the Design of Learning Environments Towards Technical Competency Development in Additive Manufacturing, 2019 IEEE Frontiers in Education Conference (FIE), Frontiers in Education Conference (FIE), 2019 IEEE, 1-2.

Garavan, T. \& O'Hanlon, N. D., (2006), Career advancement of hotel managers since graduation: a comparative study, International College of Hotel Management, Personnel Review vol. 35 (3), 252-280.

Gruden, N.; stare, A. (2018), The Influence of Behavioral Competencies on Project Performance, Project Management Journal, vol. 49(3), 98-109.

Hansen, L. W. (2002), Developing new proficiencies for human resource and industrial relations professionals, Human Resource Management Review, vol. 12(4), 513-538.

Horwitz, F. M. \& Jain h. C. (2008) Managing human resources in south Africa: a multinational firm focus, Advances in international management, vol. 21, 89-123.

Khatri, N. (2009), Emerging issues in strategic HRM in Singapore, International Journal of Manpower, vol. 20(8), 516-529.

Kim, J. Dibrell, C., Kraft, E., Marshall, D., (2020), Data analytics and performance: The moderating role of intuition-based HR management in major league baseball, Journal of Business Research, vol. 122, 204-216, 2021.

Kohont, A. \& Brewster, C., (2014), The roles and competencies of HR managers in Slovenian multinational companies, Baltic Journal of Management, vol.9(3), 294-313.

Liu, Y., Vrontis, D., Visser, M., Stokes, P., Smith, S., (2020), Talent management and the HR function in cross-cultural mergers and acquisitions: The role and impact of bi-cultural identity, Human Resource Management Review, [s. 1.],1053-4822.

Maaleki, Ali (2018), The ARZESH Competency Model: Appraisal \& Development Manager's Competency Model, Lambert Academic Publishing.

McGill, D.A., van der Vleuten, C.P.M. \& Clarke, M.J. (2013), A critical evaluation of the validity and the reliability of global competency constructs for supervisor assessment of 
junior medical trainees, Adv in Health Sci Educ 18, 701-725. https://doi.org/10.1007/s10459012-9410-Z

Mustaffa Kamal, M. F., Hassan, F., Ismail, Z., Mohd Affandi, H. (2012), Technical competency of client project manager in managing public projects in Malaysia, IEEE Colloquium on Humanities, Science and Engineering (CHUSER), Humanities, Science and Engineering (CHUSER), 3-4, 48-51.

NG, E. S. \& SEARS, G. J., (2020), "Walking the Talk on Diversity: CEO Beliefs, Moral Values, and the Implementation of Workplace Diversity Practices", Journal of Business Ethics, [s. 1.], v. 164 , n. 3, p. $437-450$.

Paine, L. S., (2015), Managing for Organizational Integrity, Harvard Business Review, https://hbr.org/1994/03/managing-for-organizational-integrity.

Piwowar-Sulej, Katarzyna (2020), Human resources development as an element of sustainable HRM - with the focus on production engineers, Journal of Cleaner Production 278.

Ransom, Montrece McNeill \& Yassine, Brianne (2019), Exploring the Development of Three Law-Based Competency Models for Practitioners, Journal of Social, Behavioral, and Health Sciences, Volume 13(1), 128-148.

Sandstrom, J. K., \& Reynolds, D. E., (2020) Leading a successful hotel: A look at the general manager's ability to utilize multiple leadership styles, International Journal of Hospitality Management, vol. 89.

Sawyer, Katie (2019), 7 Steps to Strategic Human Resource Management, https://www.deputy.com/blog/7-steps-to-strategic-human-resource-management

Sheard, A.G. (2007), Role-based perspective on leadership decision taking, Journal of Management Development, vol. 26(6), 520-622.

Vathanophas, Vichita \& Thai-ngam, Jintawee (2007), Competency Requirements for Effective Job Performance in The Thai Public Sector, Contemporary Management Research Pages, vol. $3(1), 45-70$.

www.Study.com , (2019) "Career Advancement in Human Resources", visited in September 2020. 